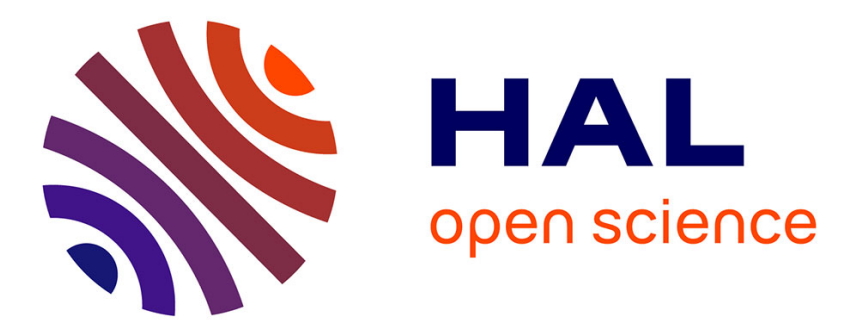

\title{
ALD Al2O3-Coated TiO2 Nanotube Layers as Anodes for Lithium-Ion Batteries
}

Hanna Sopha, Girish D. Salian, Raul Zazpe, Jan Prikryl, Ludek Hromadko, Thierry Djenizian, Jan M. Macak

\section{> To cite this version:}

Hanna Sopha, Girish D. Salian, Raul Zazpe, Jan Prikryl, Ludek Hromadko, et al.. ALD Al2O3-Coated TiO2 Nanotube Layers as Anodes for Lithium-Ion Batteries. ACS Omega, 2017, 2 (6), pp.2749 - 2756. 10.1021/acsomega.7b00463 . hal-01813840

\section{HAL Id: hal-01813840 \\ https://hal-amu.archives-ouvertes.fr/hal-01813840}

Submitted on 12 Jun 2018

HAL is a multi-disciplinary open access archive for the deposit and dissemination of scientific research documents, whether they are published or not. The documents may come from teaching and research institutions in France or abroad, or from public or private research centers.
L'archive ouverte pluridisciplinaire HAL, est destinée au dépôt et à la diffusion de documents scientifiques de niveau recherche, publiés ou non, émanant des établissements d'enseignement et de recherche français ou étrangers, des laboratoires publics ou privés.

\section{(ㅇ)(1) $\$$}

Distributed under a Creative Commons Attribution - NonCommercial - NoDerivatives 44.0 


\title{
ALD $\mathrm{Al}_{2} \mathrm{O}_{3}$-Coated $\mathrm{TiO}_{2}$ Nanotube Layers as Anodes for Lithium-Ion Batteries
}

\author{
Hanna Sopha, ${ }^{\dagger}$ Girish D. Salian, ${ }^{\dagger}$ Raul Zazpe, ${ }^{\dagger}$ Jan Prikryl, ${ }^{\dagger}$ Ludek Hromadko, ${ }^{\dagger}$ Thierry Djenizian, ${ }^{*}, \S$ \\ and Jan M. Macak* ${ }^{* \dagger}$
}

${ }^{\dagger}$ Center of Materials and Nanotechnologies, Faculty of Chemical Technology, University of Pardubice, Nam. Cs. Legii 565,53002 Pardubice, Czech Republic

${ }^{\ddagger}$ Aix Marseille Université, CNRS, Electrochemistry of Materials Research Group, MADIREL UMR 7246, F-13397 Marseille Cedex 20, France

${ }^{\S}$ IMT Mines Saint-Etienne, Center of Microelectronics in Provence, Department of Flexible Electronics, F-13541 Gardanne, France

Supporting Information

ABSTRACT: The utilization of the anodic $\mathrm{TiO}_{2}$ nanotube layers, with uniform $\mathrm{Al}_{2} \mathrm{O}_{3}$ coatings of different thicknesses (prepared by atomic layer deposition, ALD), as the new electrode material for lithium-ion batteries (LIBs), is reported herein. Electrodes with very thin $\mathrm{Al}_{2} \mathrm{O}_{3}$ coatings $(\sim 1 \mathrm{~nm})$ show a superior electrochemical performance for use in LIBs compared to that of the uncoated $\mathrm{TiO}_{2}$ nanotube layers. A more than 2 times higher areal capacity is received on these coated $\mathrm{TiO}_{2}$ nanotube layers ( 75 vs $200 \mu \mathrm{Ah} / \mathrm{cm}^{2}$ ) as well as higher rate capability and coulombic efficiency of the charging and discharging reactions. Reasons for this can be attributed to an increased mechanical stability of the $\mathrm{TiO}_{2}$ nanotube layers upon $\mathrm{Al}_{2} \mathrm{O}_{3}$ coating, as well as to an enhanced diffusion of the $\mathrm{Li}^{+}$ ions within the coated nanotube layers. In contrast, thicker $\mathrm{ALD} \mathrm{Al}_{2} \mathrm{O}_{3}$ coatings result in a blocking of the electrode surface and therefore an areal capacity decrease.

\section{INTRODUCTION}

During the last decade, $\mathrm{TiO}_{2}$ nanomaterials have widely been studied as an alternative electrode material for lithium-ion batteries (LIBs). ${ }^{1-15} \mathrm{TiO}_{2}$ has a higher lithiation potential $\left(\sim 1.6 \mathrm{~V}\right.$ vs $\left.\mathrm{Li} / \mathrm{Li}^{+}\right)$compared to that of the negative electrodes, such as graphite $\left(\sim 0.1 \mathrm{~V}\right.$ vs $\left.\mathrm{Li} / \mathrm{Li}^{+}\right)$, and therefore enhances safety of the cells and provides a good capacity retention on cycling and a low self-discharge. ${ }^{1-4}$ Furthermore, $\mathrm{TiO}_{2}$ shows low volume changes of less than $4 \%$ upon reversible insertion and extraction of $\mathrm{Li}^{+}$in the lattice. However, $\mathrm{TiO}_{2}$ also has a poor electrical conductivity and shows limited $\mathrm{Li}^{+}$uptake and slow $\mathrm{Li}^{+}$insertion kinetics. ${ }^{1-4}$ To overcome these drawbacks, nanostructured $\mathrm{TiO}_{2}$, such as mesoporous microspheres, ${ }^{5}$ nanowires, ${ }^{6,7}$ nanoparticles, ${ }^{8}$ nanoflakes, ${ }^{9}$ or $\mathrm{TiO}_{2}$ nanotubes, ${ }^{1-4,10}$ produced via different methods have been considered as anodes due to the larger specific surface area. Although most of these structures are randomly oriented and have to be deposited on the back contact of the electrode, selforganized $\mathrm{TiO}_{2}$ nanotube layers produced by electrochemical anodization of the Ti substrates consist of straight and vertically aligned nanotubes in direct electrical contact with the underlying Ti substrate. ${ }^{16}$ Another advantage of the vertically aligned nanotube layers is a direct diffusion path for the $\mathrm{Li}^{+}$ ions, resulting in a superior electrochemical performance. ${ }^{11}$
To further increase the capacity and conductivity of the $\mathrm{TiO}_{2}$ nanotubes for their use in LIBs, they have been decorated or coated with other metals and metal oxides, with higher conductivities and capacities, for example, $\mathrm{Ag},{ }^{17} \mathrm{Cu}_{6} \mathrm{Sn}_{5},{ }^{18}$ $\mathrm{Fe}_{2} \mathrm{O}_{3},{ }^{19} \mathrm{SnO},{ }^{20} \mathrm{SnO}_{2},{ }^{21,22}$ or $\mathrm{ZnO}^{23}$ Another advantage of these composite structures is that due to their hollow tubular architecture they can bear volume variations upon battery cycling without mechanical failure.

Among the various methods that can be used for the coating and decoration of the $\mathrm{TiO}_{2}$ nanotube layers, atomic layer deposition (ALD) has been the only method that creates uniform coatings of the nanotube walls from inside as well as outside, with a precise control of the coating thickness according to the deposition cycles. ${ }^{24-26}$ However, although several reports can be found on utilization of the ALD coatings of different materials to modify the electrodes for lithium-ion battery application, ${ }^{27-33}$ only one publication reports on the use of ALD to coat an anode prepared from an anodic $\mathrm{TiO}_{2}$ nanotube layer with $\mathrm{ZnO}^{23}$

Usually, passivation layers on the electrode surfaces (solid electrolyte interphase (SEI)) are formed via decomposition of

Received: April 15, 2017

Accepted: June 5, 2017

Published: June 16, 2017 


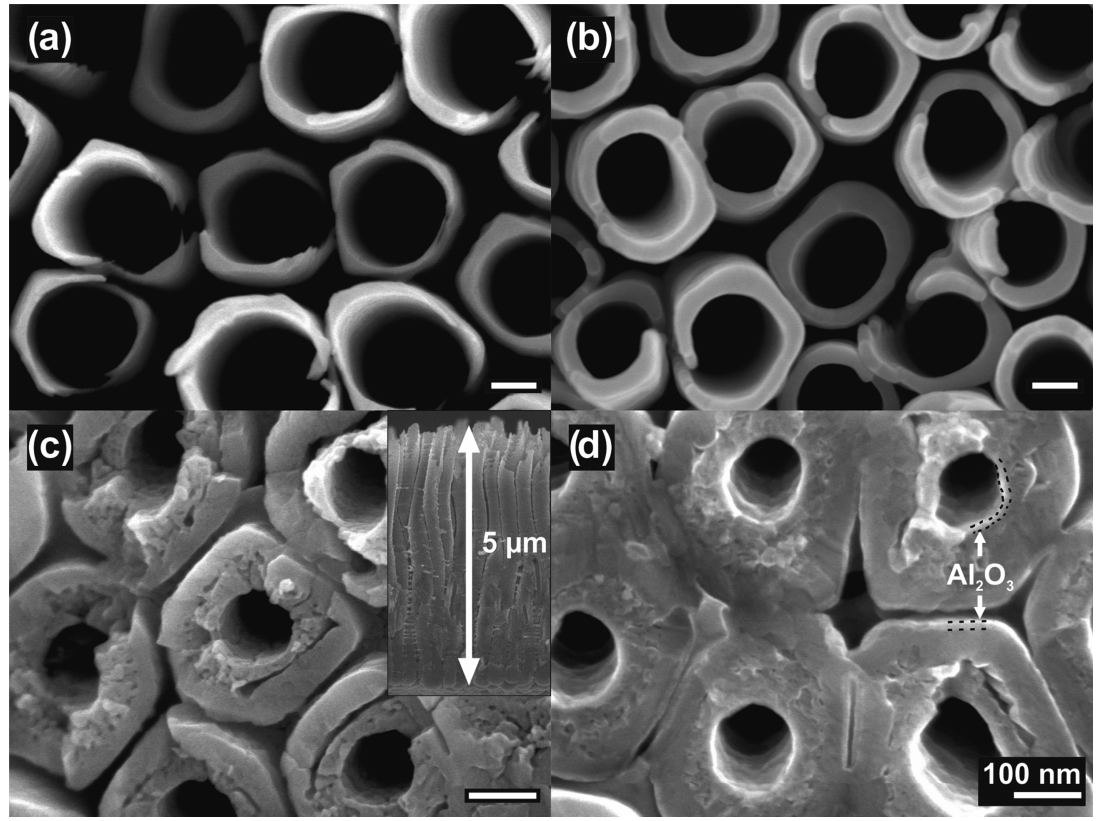

Figure 1. SEM images of the top (a, b) and bottom parts (c, d) of the uncoated $\mathrm{TiO}_{2}$ nanotube layer (a, c) and $10 \mathrm{~nm} \mathrm{ALD} \mathrm{Al}_{2} \mathrm{O}_{3}$-coated $\mathrm{TiO}_{2}$ nanotube layer $(\mathrm{b}, \mathrm{d})$. The inset in $(\mathrm{c})$ shows an illustrative image of the whole $\mathrm{TiO}_{2}$ nanotube layer, revealing a thickness of $\sim 5 \mu \mathrm{m}$.

the electrolyte and are necessary to prevent further electrolyte decomposition that often leads to unsafe operation conditions. ${ }^{34}$ However, $\mathrm{Li}^{+}$ions are consumed for SEI formation, reducing the overall capacity of the electrode. Thin layers of $\mathrm{Al}_{2} \mathrm{O}_{3}$ can suppress the $\mathrm{SEI}$ formation and undesirable side reactions. Several reports demonstrated the beneficial effect of the $\mathrm{Al}_{2} \mathrm{O}_{3}$ coatings on electrodes prepared from different materials for passivation of the electrode surfaces. ${ }^{35-43}$ At the same time, $\mathrm{Al}_{2} \mathrm{O}_{3}$ acts as a substitute for the SEI layer due to the formation of $\mathrm{Li}-\mathrm{Al}-\mathrm{O}$ in the first few cycles, which is a good ionic conductor, blocking the electron transfer efficiently. ${ }^{39,40,43}$

In this work, for the first time, the vertically aligned $\mathrm{TiO}_{2}$ nanotube layers prepared by anodization were coated with thin $\mathrm{Al}_{2} \mathrm{O}_{3}$ layers of different thicknesses by ALD (i.e., 0.2, 1, 2, 5, and $10 \mathrm{~nm}$ corresponding to of $2,9,18,46$, and 92 ALD cycles, respectively) and examined as potential anodes for LIBs. The results were compared to that of the uncoated $\mathrm{TiO}_{2}$ nanotube layers.

\section{EXPERIMENTAL SECTION}

$\mathrm{TiO}_{2}$ nanotube layers, with a thickness of $\sim 5 \mu \mathrm{m}$ and a diameter of $\sim 230 \mathrm{~nm}$, were prepared according to the previously published work. ${ }^{44}$ In brief, Ti foils (Sigma Aldrich, $0.127 \mathrm{~mm}$ thick, $99.7 \%$ purity) were degreased in isopropanol and acetone and afterwards anodized in an ethylene glycolbased electrolyte containing $150 \mathrm{mM} \mathrm{NH}_{4} \mathrm{~F}$ and $10 \mathrm{vol} \% \mathrm{H}_{2} \mathrm{O}$ at $100 \mathrm{~V}$ for $4 \mathrm{~h}$. The electrochemical cell consisted of a highvoltage potentiostat (PGU-200V; Elektroniklabor $\mathrm{GmbH}$ ) in a two-electrode configuration, with a $\mathrm{Pt}$ foil as the counter electrode and $\mathrm{Ti}$ foil as the working electrode. After anodization, the nanotube layers were sonicated in isopropanol and dried in air. Before further use, all of the $\mathrm{TiO}_{2}$ nanotube layers were annealed in a muffle oven at $400{ }^{\circ} \mathrm{C}$ to receive a crystalline anatase phase.

The prepared $\mathrm{TiO}_{2}$ nanotube layers were coated with $\mathrm{Al}_{2} \mathrm{O}_{3}$ layers of different thicknesses using an ALD tool (thermal ALD, TFS 200, Beneq). Trimethylaluminum (TMA, Strem, elec. grade, $99.999+\%)$ and deionized water $(18 \mathrm{M} \Omega)$ were used as aluminum and oxygen precursors, respectively. Under these deposition conditions, one $\mathrm{ALD} \mathrm{Al}_{2} \mathrm{O}_{3}$ growth cycle was defined by the following sequence: TMA pulse (100 ms) $-\mathrm{N}_{2}$ purge $(2 \mathrm{~s})-\mathrm{H}_{2} \mathrm{O}$ pulse $(100 \mathrm{~ms})-\mathrm{N}_{2}$ purge $(3 \mathrm{~s})$. All processes were carried out at a temperature of $200{ }^{\circ} \mathrm{C}$, using $\mathrm{N}_{2}$ (99.9999\%) as the carrier gas, at a flow rate of $400 \mathrm{sccm} . \mathrm{Al}_{2} \mathrm{O}_{3}$ coatings of different thicknesses were deposited within the $\mathrm{TiO}_{2}$ nanotube layers. The number of cycles required for the different $\mathrm{Al}_{2} \mathrm{O}_{3}$ thicknesses was estimated from the growth per cycle value of the $\mathrm{Al}_{2} \mathrm{O}_{3}$ process at $200{ }^{\circ} \mathrm{C}(\sim 1.1 \AA /$ cycle $)$. Thus, ALD processes of 2, 9, 18, 46, and 92 cycles led to nominal $\mathrm{Al}_{2} \mathrm{O}_{3}$ coating thicknesses of $0.2,1,2,5$, and $10 \mathrm{~nm}$, respectively.

The structure and morphology of the $\mathrm{TiO}_{2}$ nanotube layers were characterized by a field-emission electron microscope (FE-SEM JEOL JSM 7500F). Dimensions of the nanotubes were measured and statistically evaluated using proprietary Nanomeasure software.

The electrochemical performance of the $\mathrm{ALD} \mathrm{Al}_{2} \mathrm{O}_{3}$-coated $\mathrm{TiO}_{2}$ nanotube layers was studied using Swagelok-type cells. The $\mathrm{TiO}_{2}$ nanotube layers were assembled with metallic $\mathrm{Li}$ (Aldrich) as the counter electrode, with a glass fiber (Whatman) used as a separator. The electrolyte consisted of a solution of $1 \mathrm{M} \mathrm{LiPF}_{6}$ in ethylene carbonate (EC)/diethyl carbonate (DEC) (1:1, in w/w) (Sigma Aldrich). The cells were assembled in an argon-filled glovebox (MBraun, Germany), with $<0.5$ ppm $\mathrm{H}_{2} \mathrm{O}$ and $<0.5 \mathrm{ppm} \mathrm{O}_{2}$ atmosphere. Galvanostatic tests were carried out using a VMP3 potentiostat (Bio Logic, France). The cells were cycled at $1 \mathrm{C}(\sim 1 \mathrm{~h}$ charge/ discharge) in a potential window of $1-3 \mathrm{~V}$. The current was applied considering the mass of the $\mathrm{TiO}_{2}$ nanotube layers and was calculated considering a density of $4.23 \mathrm{~g} / \mathrm{cm}^{3}$ and porosity of $76 \%$. The porosity calculation is based on the amount of the $\mathrm{TiO}_{2}$ nanotubes per $\mathrm{cm}^{2}$. The volume occupied by the $\mathrm{TiO}_{2}$ nanotubes was calculated by subtracting the inner tube area from outer tube area. 

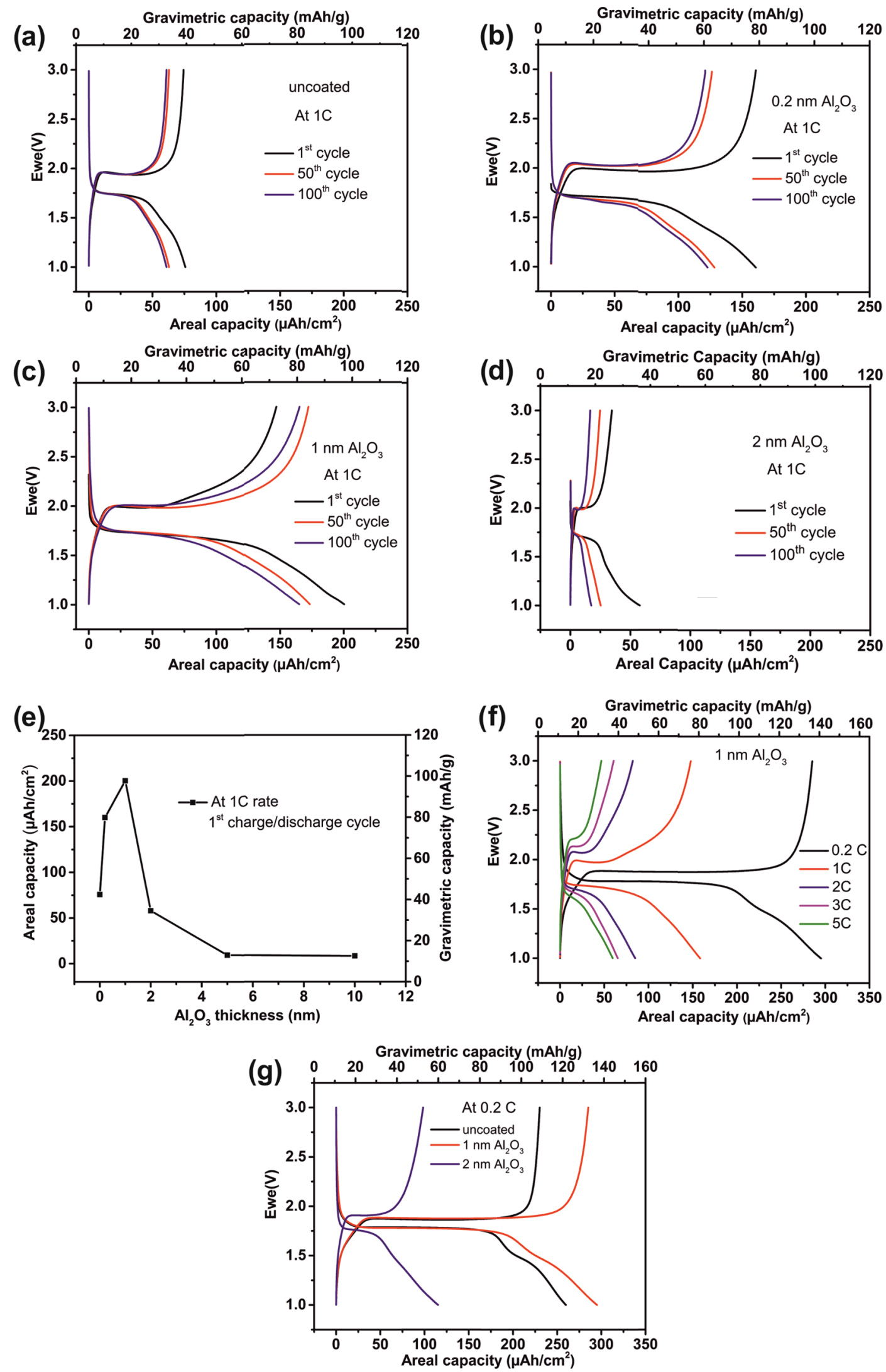

Figure 2. Galvanostatic cycling at $1 \mathrm{C}$ rate of the (a) uncoated (0 cycles), (b) $0.2 \mathrm{~nm}$ ( 2 cycles), (c) $1 \mathrm{~nm}$ ( 9 cycles), and (d) $2 \mathrm{~nm}$ (18 cycles) ALD $\mathrm{Al}_{2} \mathrm{O}_{3}$-coated $\mathrm{TiO}_{2}$ nanotube layers, (e) the discharge capacity of the first charge/discharge cycle of the $\mathrm{TiO}_{2}$ nanotube layers coated with $\mathrm{Al}_{2} \mathrm{O}_{3}$ of

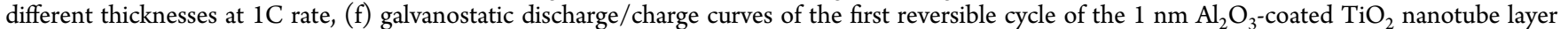
at different $\mathrm{C}$ rates, and $(\mathrm{g})$ galvanostatic discharge/charge curves of the first reversible cycle of the uncoated, and the 1 and $2 \mathrm{~nm} \mathrm{ALD} \mathrm{Al}_{2} \mathrm{O}_{3}$-coated $\mathrm{TiO}_{2}$ nanotube layer at $\mathrm{C} / 5$. 
The chronoamperometric (CA) tests were conducted in a three-electrode Swagelok cell. The uncoated and the 1 and 2 nm ALD $\mathrm{Al}_{2} \mathrm{O}_{3}$-coated $\mathrm{TiO}_{2}$ nanotube layer electrodes were assembled against one $\mathrm{Li}$ foil serving as a counter electrode and another $\mathrm{Li}$ foil as a reference electrode. Two separators were placed between each electrode soaked in a solution of $1 \mathrm{M}$ $\mathrm{LiPF}_{6}$ in EC/DEC (1:1, in w/w) obtained from Sigma Aldrich. The CA tests were performed by applying a constant potential of $1.7 \mathrm{~V}$ for $80 \mathrm{~s}$ using a VMP3 potentiostat-galvanostat (Bio Logic).

For electrochemical impedance spectroscopy (EIS) measurements, the nanotube layers were assembled in a three-electrode system, with separate $\mathrm{Li}$ foils as the reference and counter electrodes, using Whatman paper as the separator. EC/DEC with $1 \mathrm{M} \mathrm{LiPF}_{6}$ was used as the electrolyte. The cells were kept for $24 \mathrm{~h}$ at open circuit potential (OCP) to get stabilized. The AC impedance measurements were carried out using a VMP3 Biologic Potentiostat at OCP in a frequency range of $100 \mathrm{kHz}$ to $10 \mathrm{mHz}$ at amplitude of $10 \mathrm{mV}$. The obtained spectra were fitted by "Z-fit" in the EC-Lab software (Bio Logic).

\section{RESULTS AND DISCUSSION}

Figure 1 shows SEM images of the top ( $a, b)$ and bottom parts (c, d) of the uncoated $\mathrm{TiO}_{2}$ nanotube layer and the $10 \mathrm{~nm}$ $\mathrm{Al}_{2} \mathrm{O}_{3}$-coated $\mathrm{TiO}_{2}$ nanotube layer. As can be seen, the wall thickness on top of the nanotube layers increased from the uncoated to $10 \mathrm{~nm} \mathrm{ALD} \mathrm{Al}_{2} \mathrm{O}_{3}$-coated $\mathrm{TiO}_{2}$ nanotube layers. At the bottom parts, thin layers of $\mathrm{Al}_{2} \mathrm{O}_{3}$ could be observed on the inside as well as outside of the nanotube walls. The thin layers were visible due to the different mass contrasts between $\mathrm{TiO}_{2}$ and $\mathrm{Al}_{2} \mathrm{O}_{3}$. In line with our previous work, the $\mathrm{ALD} \mathrm{Al}_{2} \mathrm{O}_{3}$ coatings on the $\mathrm{TiO}_{2}$ nanotube layers were very uniform and homogenous. $^{26}$

It has to be noted that the double-walled structure that can be seen at the bottom parts of both the uncoated and coated nanotube layers is an intrinsic feature of the $\mathrm{TiO}_{2}$ nanotube layers prepared in ethylene glycol-based electrolytes and is well known from the literature. ${ }^{4}$

Figure $2 \mathrm{a}-\mathrm{d}$ shows the charge/discharge profiles obtained by chronopotentiometry in the potential range of $1.0-3.0 \mathrm{~V}$ for the uncoated $\mathrm{TiO}_{2}$ nanotubes (taken as reference), $0.2 \mathrm{~nm}$ $\mathrm{Al}_{2} \mathrm{O}_{3}, 1 \mathrm{~nm} \mathrm{Al}_{2} \mathrm{O}_{3}$, and $2 \mathrm{~nm}$ ALD $\mathrm{Al}_{2} \mathrm{O}_{3}$-coated $\mathrm{TiO}_{2}$ nanotube layers recorded at $1 \mathrm{C}$. In all of the cases, the presence of two plateaus is attributed to the reversible insertion of $\mathrm{Li}^{+}$into crystalline anatase $\mathrm{TiO}_{2}$. In the discharge profile, the plateau at $\sim 1.75 \mathrm{~V}$ corresponds to the accommodation of $\mathrm{Li}^{+}$, according to a reduction reaction. In the charge profile, the plateau at $\sim 1.95 \mathrm{~V}$ was induced by the extraction of $\mathrm{Li}^{+}$, according to an oxidation reaction. The reversible insertion reaction of $\mathrm{Li}^{+}$in anatase $\mathrm{TiO}_{2}$ is given by eq $1^{1}$

$$
\mathrm{TiO}_{2}+x \mathrm{Li}^{+}+x \mathrm{e}^{-} \leftrightarrow \mathrm{Li}_{x} \mathrm{TiO}_{2} \text { for } 0 \leq x \leq 0.5
$$

As can be seen in Figure $2 \mathrm{a}-\mathrm{d}$, the presence of $\mathrm{Al}_{2} \mathrm{O}_{3}$ coating clearly had a strong influence on the electrochemical performance of the $\mathrm{TiO}_{2}$ nanotube electrodes. Indeed, the areal and gravimetric capacities grew with increasing $\mathrm{Al}_{2} \mathrm{O}_{3}$ thickness until a maximum value for the $1 \mathrm{~nm} \mathrm{Al}_{2} \mathrm{O}_{3}$-coated $\mathrm{TiO}_{2}$ nanotube layers and then decreased for the $\mathrm{TiO}_{2}$ nanotube layers with thicker coatings. The gravimetric capacities were calculated on the basis of an estimated porosity of $76 \%$. It must be noted that the porosity of the nanotube layers is just an estimated value and therefore the gravimetric capacities are not as accurate as the areal capacities. The theoretical capacity of $\mathrm{TiO}_{2}$ is $336 \mathrm{mAh} / \mathrm{g}$ for $1 \mathrm{~mol}$ of Li-ion insertion. For the fully reversible reaction, $\mathrm{TiO}_{2}$ inserts a maximum of $0.5 \mathrm{~mol} \mathrm{Li}$ ions, giving a theoretical capacity of $168 \mathrm{mAh} / \mathrm{g}$. Thus, the theoretical capacity is not reached for $1 \mathrm{~nm}$ coatings, according to our porosity calculation. However, the calculated gravimetric capacity for the nanotube layers with $1 \mathrm{~nm}$ coating was 149 $\mathrm{mAh} / \mathrm{g}$ for the first cycle at a $\mathrm{C}$ rate of $\mathrm{C} / 5$ (Figure $2 \mathrm{f}, \mathrm{g}$ ), which is very close to the theoretical value of $168 \mathrm{mAh} / \mathrm{g}$, especially taking the above mentioned accuracy into account.

Figure $2 \mathrm{e}$ shows dependence of the first discharge capacity delivered by the $\mathrm{TiO}_{2}$ nanotube layers coated by $\mathrm{Al}_{2} \mathrm{O}_{3}$, using various coating thicknesses. After being coated with $1 \mathrm{~nm}$ $\mathrm{Al}_{2} \mathrm{O}_{3}$, the areal capacity was more than 2 times higher compared to that of the reference $\left(\sim 200 \mathrm{vs} \sim 75 \mu \mathrm{Ah} / \mathrm{cm}^{2}\right.$, respectively), whereas for thicker $\mathrm{Al}_{2} \mathrm{O}_{3}$ coatings, the areal capacity decreased significantly. More remarkably, after the charge/discharge tests, the capacity remained almost 3 times higher than that for the reference $\left(\sim 164\right.$ vs $\sim 60 \mu \mathrm{Ah} / \mathrm{cm}^{2}$, respectively).

Reasons for the enhancement of capacity on the $\mathrm{Al}_{2} \mathrm{O}_{3}$ coated $\mathrm{TiO}_{2}$ nanotube layers are at least 2 -fold. At first, an inhibition of the significant volume changes of the $\mathrm{TiO}_{2}$ nanotubes during $\mathrm{Li}$ insertion due to an improved mechanical stability should be considered. An improved mechanical and chemical stability of the $\mathrm{ALD} \mathrm{Al}_{2} \mathrm{O}_{3}$-coated $\mathrm{TiO}_{2}$ nanotube arrays was recently reported by the Macak group, ${ }^{46}$ showing that already thin $\mathrm{Al}_{2} \mathrm{O}_{3}$ coatings of $1 \mathrm{~nm}$ have a beneficial effect. Moreover, it was reported that an addition of $\mathrm{Al}_{2} \mathrm{O}_{3}$ can stabilize the mesoporous anatase $\mathrm{TiO}_{2}$ structures upon $\mathrm{Li}$ insertion. ${ }^{47}$ However, SEM analyses of the electrodes was carried out after 100 charge/discharge cycles, presented in Figure 2. All of the nanotube layers preserved their architecture (see Figure S1) without any noticeable change or damage.

The second reason for the enhanced capacity is a better diffusion of the $\mathrm{Li}^{+}$ions within the $\mathrm{Al}_{2} \mathrm{O}_{3}$-coated $\mathrm{TiO}_{2}$ nanotube layers, which might be explained by changes in the $\mathrm{Al}_{2} \mathrm{O}_{3}$ layer upon galvanostatic experiments. Xiao et al. ${ }^{41}$ found that the structure of the ultrathin $\mathrm{Al}_{2} \mathrm{O}_{3}$ changes to $\mathrm{Al}_{2} \mathrm{O}_{3} / \mathrm{AlF}_{3}$ during cycling, providing a better $\mathrm{Li}^{+}$-ion conductivity and formation of $\mathrm{LiAlO}_{2}$ on the surface that can promote $\mathrm{Li}$ insertion by reducing the associated energy barrier.

However, on the basis of Figure 2, a suppression of the SEI layer due to $\mathrm{Al}_{2} \mathrm{O}_{3}$ coatings can be excluded, even though $\mathrm{Al}_{2} \mathrm{O}_{3}$ coatings are typically discussed in the literature (3, $^{30,43}$ as inhibitors of SEI formation. It is also known that on the $\mathrm{TiO}_{2}$ anodes only very thin SEI layers are formed when electrochemical cycling experiments are performed at potentials higher than $1 \mathrm{~V}^{2,11,48}$ Indeed, from Figure 2 it is clear that the capacity loss during the first charge/discharge cycle (when SEI typically forms) was very low for the uncoated $\mathrm{TiO}_{2}$ nanotube layer, suggesting that only a very thin SEI layer was formed. In contrast, the capacity loss during the first charge/discharge cycle was much more pronounced for the $\mathrm{Al}_{2} \mathrm{O}_{3}$-coated $\mathrm{TiO}_{2}$ nanotube layers. This high irreversible capacity of the ALD $\mathrm{Al}_{2} \mathrm{O}_{3}$-coated $\mathrm{TiO}_{2}$ nanotube layers might be caused by $\mathrm{Li}$ containing $\mathrm{Al}_{2} \mathrm{O}_{3}$ phase formation. ${ }^{39}$ It is believed that the insulating $\mathrm{Al}_{2} \mathrm{O}_{3}$ layers cause a potential drop and also slow down $\mathrm{Li}$ diffusion during the first cycle. Thereafter, $\mathrm{Al}_{2} \mathrm{O}_{3}$ reacts with the electrolyte and forms $\mathrm{AlF}_{3}$, which facilitates the charge transfer. ${ }^{39}$ It was also suggested that lithiation of the $\mathrm{Al}_{2} \mathrm{O}_{3}$ coating layer proceeds until a thermodynamically stable phase is reached (corresponding to $\mathrm{Li}_{3.4} \mathrm{Al}_{2} \mathrm{O}_{3}$ ). ${ }^{49}$ The extra $\mathrm{Li}^{+}$ions 
then overflow into the electrode passing through the coating layer. If the $\mathrm{Al}_{2} \mathrm{O}_{3}$ coating layer is too thick, a longer time would be needed until the thermodynamically stable phase is reached. ${ }^{49}$ This explains that thicker $\mathrm{Al}_{2} \mathrm{O}_{3}$ coatings blocked $\mathrm{Li}$ diffusion into $\mathrm{TiO}_{2}$ and therefore the areal capacity decreased for the thicker $\mathrm{Al}_{2} \mathrm{O}_{3}$ coatings within the $\mathrm{TiO}_{2}$ nanotube layers, as can be seen in Figure 2e. Furthermore, a higher amount of $\mathrm{Li}^{+}$from the electrolyte is needed to build a thermodynamically stable phase $\mathrm{Li}_{3.4} \mathrm{Al}_{2} \mathrm{O}_{3}$ for the thicker $\mathrm{Al}_{2} \mathrm{O}_{3}$ layers, reducing the charge/discharge capacities.

Additionally, calculations of the diffusion coefficients using chronoamperometry and the Cottrell equation were carried out after cycling the cell for three cycles at $1 \mathrm{C}$ rate to facilitate formation of the $\mathrm{Li}-\mathrm{Al}-\mathrm{O}$ phase (see Figure S2). The diffusion coefficients calculated for the uncoated ( 0 cycles ALD) and 1 $\mathrm{nm}$ (9 cycles) ALD $\mathrm{Al}_{2} \mathrm{O}_{3}$-coated $\mathrm{TiO}_{2}$ nanotube layers were 1 $\times 10^{-16}$ and $1.44 \times 10^{-16} \mathrm{~cm}^{2} \mathrm{~s}^{-1}$, respectively, which shows the positive influence of $\mathrm{Al}_{2} \mathrm{O}_{3}$ on $\mathrm{Li}^{+}$diffusion. For the $2 \mathrm{~nm}$ (18 cycles) $\mathrm{ALD} \mathrm{Al}_{2} \mathrm{O}_{3}$-coated $\mathrm{TiO}_{2}$ nanotube layers, the diffusion coefficient was estimated to be $9 \times 10^{-17} \mathrm{~cm}^{2} \mathrm{~s}^{-1}$, suggesting that at a higher $\mathrm{Al}_{2} \mathrm{O}_{3}$ thickness $\mathrm{Li}^{+}$diffusion is hindered.

Lindstrom et al. ${ }^{50}$ have reported an $\mathrm{Li}^{+}$diffusion coefficient of $1 \times 10^{-17} \mathrm{~cm}^{2} \mathrm{~s}^{-1}$ for nanoporous anatase $\mathrm{TiO}_{2}$ using chronoamperometry. Apart from the positive influence of the thin $\mathrm{Al}_{2} \mathrm{O}_{3}$ coating on the $\mathrm{TiO}_{2}$ nanotubes shown for our samples, the higher $\mathrm{Li}^{+}$diffusion also indicates that onedimensional nanomaterials (like the vertical aligned nanotubes) could help promote better charge diffusion compared with nanoporous films.

These results are also in agreement with findings reported in the literature. Lipson et al. ${ }^{43}$ observed for an $\mathrm{ALD} \mathrm{Al}_{2} \mathrm{O}_{3}$-coated $\mathrm{MnO}$ electrode that $\mathrm{Li}^{+}$was unable to diffuse through the thick $\mathrm{Al}_{2} \mathrm{O}_{3}$ films and thus the thick $\mathrm{ALD} \mathrm{Al}_{2} \mathrm{O}_{3}$ films blocked the electrode surface. Ultrathin $\mathrm{Al}_{2} \mathrm{O}_{3}$ films (9 $\AA$ thick), however, inhibited SEI formation without blocking the electrode surface.

Considering the superior performance for the $1 \mathrm{~nm} \mathrm{Al}_{2} \mathrm{O}_{3}$ coated $\mathrm{TiO}_{2}$ nanotube layer at $1 \mathrm{C}$, cycling tests at faster kinetics have been explored to study the rate capability of this coating in more detail. As shown in Figure 2f, the discharge capacities of the first reversible cycle were $\sim 295, \sim 158, \sim 84, \sim 65$, and $\sim 59$ $\mu \mathrm{Ah} / \mathrm{cm}^{2}$ for $\mathrm{C} / 5,1 \mathrm{C}, 2 \mathrm{C}, 3 \mathrm{C}$, and $5 \mathrm{C}$, respectively. As expected, the areal capacity decreased with an increased $\mathrm{C}$ rate due to the higher applied current density. Figure $2 \mathrm{~g}$ shows the galvanostatic discharge/charge curves of the first reversible cycle of the uncoated and the 1 and $2 \mathrm{~nm} \mathrm{ALD} \mathrm{Al}_{2} \mathrm{O}_{3}$-coated $\mathrm{TiO}_{2}$ nanotube layer at $0.2 \mathrm{C}$. As can be seen, the theoretical gravimetric capacity was just reached in the case of the $1 \mathrm{~nm}$ ALD $\mathrm{Al}_{2} \mathrm{O}_{3}$-coated $\mathrm{TiO}_{2}$ nanotube layer, taking accuracy of the porosity calculation into account. It can be pointed out that these high capacity values obtained for the $1 \mathrm{~nm} \mathrm{ALD} \mathrm{Al}_{2} \mathrm{O}_{3}$ coated $\mathrm{TiO}_{2}$ nanotube layer were only obtained by the uncoated $\mathrm{TiO}_{2}$ nanotube layers at very slow kinetics $(\mathrm{C} / 10)$.

The coulombic efficiencies (CEs) for the first charge/ discharge cycles for the uncoated and $1 \mathrm{~nm} \mathrm{ALD} \mathrm{Al}_{2} \mathrm{O}_{3}$-coated $\mathrm{TiO}_{2}$ nanotube layers are given in Table 1 . As expected, the CE for the uncoated $\mathrm{TiO}_{2}$ nanotube layer was very high from the first charge/discharge cycle. The CE of the $1 \mathrm{~nm} \mathrm{ALD} \mathrm{Al}_{2} \mathrm{O}_{3}$ coated $\mathrm{TiO}_{2}$ nanotube layer, however, is comparably lower during the first 10 cycles. This is probably due to the formation of the $\mathrm{Li}-\mathrm{Al}-\mathrm{O}$ phase during the first charge/discharge cycles.

Figure $3 \mathrm{a}$ depicts the discharge capacities of the uncoated $\mathrm{TiO}_{2}$ nanotube layer and the $1 \mathrm{~nm} \mathrm{Al}_{2} \mathrm{O}_{3}$-coated $\mathrm{TiO}_{2}$ nanotube layer for the 100 charge/discharge cycles at $1 \mathrm{C}$.
Table 1. CEs for the First Charge/Discharge Cycles for the Uncoated and $1 \mathrm{~nm}$ ALD $\mathrm{Al}_{2} \mathrm{O}_{3}$-Coated $\mathrm{TiO}_{2}$ Nanotube Layers

\begin{tabular}{ccc}
$\begin{array}{c}\mathrm{CE} \text { of the uncoated } \\
\text { charge/discharge } \\
\text { cycle no. }\end{array}$ & $\begin{array}{c}\mathrm{CE} \text { of the } 1 \mathrm{~nm} \text { ALD } \\
\mathrm{TiO}_{2} \text { nanotube layer } \\
(\%)\end{array}$ & $\begin{array}{c}\mathrm{CE} \text { of } \\
\mathrm{Al}_{2} \mathrm{O}_{3} \text {-coated } \mathrm{TiO} \\
\text { layer }(\%)\end{array}$ \\
1 & 92.2 & 73.2 \\
2 & 98.85 & 93.03 \\
3 & 98.35 & 93.80 \\
5 & 99.05 & 95.67 \\
10 & 99.13 & 97.54 \\
\hline
\end{tabular}

After an initial decrease of the capacity during the initial discharge cycle, more than 2 times higher capacity was attained for the $1 \mathrm{~nm} \mathrm{Al}_{2} \mathrm{O}_{3}$-coated $\mathrm{TiO}_{2}$ nanotube layer compared to that of the reference. However, a very slight decrease of the discharge capacity could be seen for the uncoated nanotube layer, whereas for the $1 \mathrm{~nm} \mathrm{Al}_{2} \mathrm{O}_{3}$-coated $\mathrm{TiO}_{2}$ nanotube layer, an increase of the discharge capacity was clearly visible during the first cycles. This increase might be explained with an increase in conductivity of the $\mathrm{Al}_{2} \mathrm{O}_{3}$ coating during the electrochemical cycling, as explained above. All in all, the 2 -fold difference was preserved even after extensive cycling.

EIS measurements were performed to further elucidate the effect of the $\mathrm{Al}_{2} \mathrm{O}_{3}$ coatings on $\mathrm{TiO}_{2}$ nanotube layers. Figure $3 \mathrm{~b}$ shows the overlaid impedance spectra of both samples and their fittings at OCP. The figure demonstrates the excellent agreement between the experimental and fit data. The equivalent circuit for the EIS spectra of the uncoated $\mathrm{TiO}_{2}$ nanotube layer is represented by $\left[R_{\mathrm{e}}+R_{\mathrm{CT}} / Q_{\mathrm{CT}}+Q\right]$, shown in Figure $4 \mathrm{a}$, where $R$ represents resistors and $Q$ constant phase elements (CPEs). $R_{\mathrm{e}}$ represents essentially the resistance of the electrolyte. The depressed semicircle at the medium frequency and the sloped line at low frequencies represent the chargetransfer impedance $\left(R_{\mathrm{CT}} / Q_{\mathrm{CT}}\right)$ of the lithium intercalation process and the capacitive effect $(Q)$, respectively. From the fit data of the EIS spectra, $R_{\mathrm{CT}}$ for the uncoated $\mathrm{TiO}_{2}$ nanotube layer was $692.2 \Omega$.

The EIS spectrum for the $\mathrm{Al}_{2} \mathrm{O}_{3}$-coated $\mathrm{TiO}_{2}$ nanotube layer consists of two semicircles. The first depressed semicircle at high frequency is attributed to the impedance due to the $\mathrm{Al}_{2} \mathrm{O}_{3}$ coating on the nanotube layer ${ }^{51}$ and the second semicircle in the medium frequency range to the impedance due to the charge transfer resistance. The equivalent circuit shown in Figure $4 \mathrm{~b}$ for the $1 \mathrm{~nm} \mathrm{Al}_{2} \mathrm{O}_{3}$-coated $\mathrm{TiO}_{2}$ nanotube layer is $\left[R_{\mathrm{e}}\right.$ $\left.+R_{\mathrm{Al}_{2} \mathrm{O}_{3}} / Q_{\mathrm{Al}_{2} \mathrm{O}_{3}}+R_{\mathrm{CT}} / Q_{\mathrm{CT}}+Q\right]$. From the fit data, $R_{\mathrm{Al}_{2} \mathrm{O}_{3}}$ and $R_{\mathrm{CT}}$ were calculated to be 56.07 and $289.1 \Omega$, respectively. The exponent for the last CPE was 0.8 for both samples, which suggests largely a capacitive effect. The lower $R_{\mathrm{CT}}$ for the $1 \mathrm{~nm}$ ALD $\mathrm{Al}_{2} \mathrm{O}_{3}$-coated $\mathrm{TiO}_{2}$ nanotube layer revealed a positive influence of the $\mathrm{Al}_{2} \mathrm{O}_{3}$ coating in enhancing the electronic conductivity of the $\mathrm{TiO}_{2}$ nanotube layer.

Another advantage of the $\mathrm{Al}_{2} \mathrm{O}_{3}$ coating is that it can also prevent the electrolyte side reactions with $\mathrm{TiO}_{2}$ during the charge/discharge process, thereby suppressing any passivation layer on the surface of the $\mathrm{TiO}_{2}$ nanotube layer.

\section{CONCLUSIONS}

In summary, it was demonstrated that the ALD coating of the $\mathrm{TiO}_{2}$ nanotube layers, with thin layers $(\leq 1 \mathrm{~nm})$ of $\mathrm{Al}_{2} \mathrm{O}_{3}$, have a beneficial effect on the areal capacity and cycling behavior of the $\mathrm{TiO}_{2}$ nanotube layers. This is due to an increased 

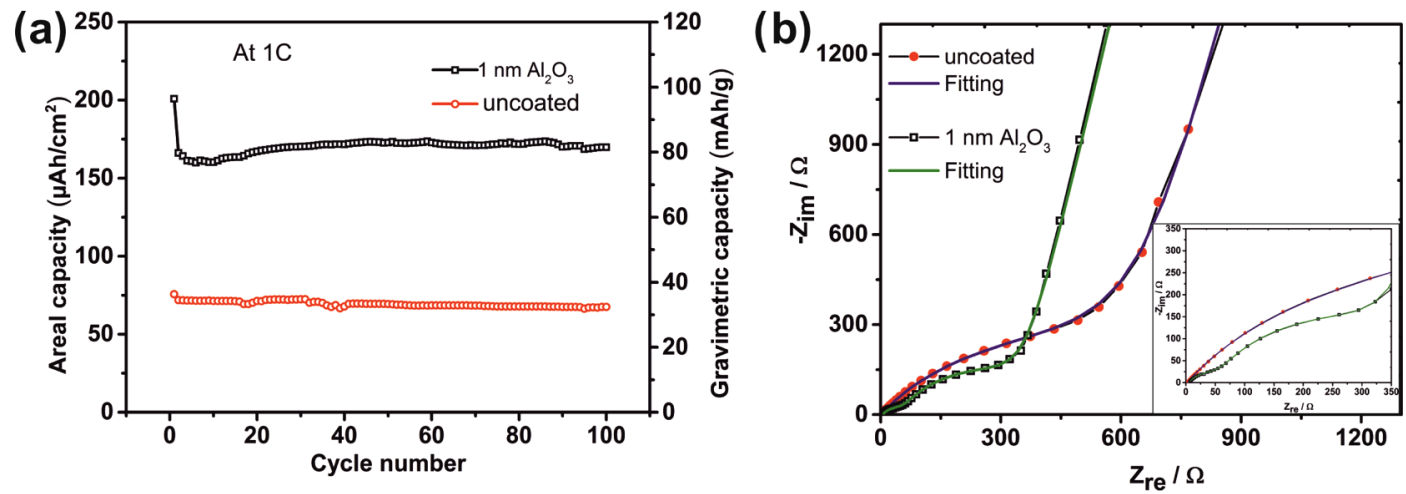

Figure 3. Discharge capacity as a function of the discharge cycle number of the cells at $1 \mathrm{C}$ rate (a) and Nyquist plots (at $\mathrm{OCP}$ vs $\left.\mathrm{Li} / \mathrm{Li}^{+}\right)(\mathrm{b})$ for the uncoated and $1 \mathrm{~nm} \mathrm{ALD} \mathrm{Al} \mathrm{O}_{3}$-coated $\mathrm{TiO}_{2}$ nanotube layers. The inset in (b) shows a higher magnification of the first semicycle.

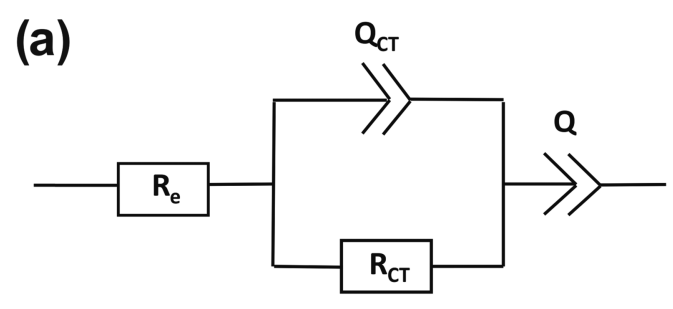

(b)

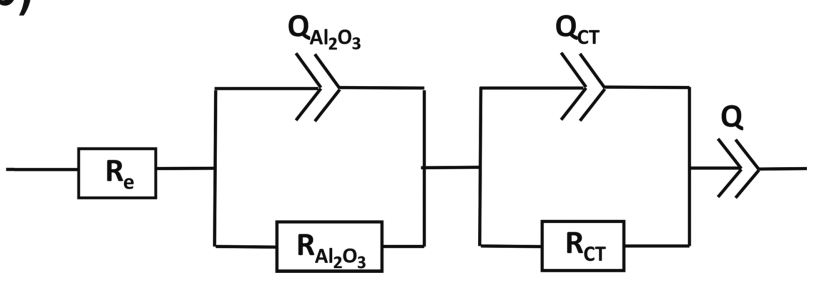

Figure 4. Equivalent circuits for the EIS plots of the (a) uncoated and (b) $1 \mathrm{~nm} \mathrm{ALD} \mathrm{Al}_{2} \mathrm{O}_{3}$-coated $\mathrm{TiO}_{2}$ nanotube layers.

mechanical stability of the nanotube layers upon $\mathrm{Al}_{2} \mathrm{O}_{3}$ coating and a better diffusion of the $\mathrm{Li}^{+}$ions within the $\mathrm{Al}_{2} \mathrm{O}_{3}$-coated $\mathrm{TiO}_{2}$ nanotube layers. On the other hand, $\mathrm{Al}_{2} \mathrm{O}_{3}$ coatings with thickness $>2 \mathrm{~nm}$ show a reduced capacity. The approach presented in this work is important for future applications of the $\mathrm{TiO}_{2}$ nanotube layers, where a thin and highly conformal coating of the secondary material can significantly enhance the performance of the $\mathrm{TiO}_{2}$ nanotube layers and explore these composite nanotube layers for new applications, previously unfeasible for the uncoated (bare) $\mathrm{TiO}_{2}$ nanotube layers.

\section{ASSOCIATED CONTENT}

\section{S Supporting Information}

The Supporting Information is available free of charge on the ACS Publications website at DOI: 10.1021/acsomega.7b00463.

Postcycling SEM images; chronoamperometric plots (PDF)

\section{AUTHOR INFORMATION}

\section{Corresponding Authors}

*E-mail: thierry.djenizian@mines-stetienne.fr (T.D.).

*E-mail: jan.macak@upce.cz (J.M.M.).

ORCID

Jan M. Macak: 0000-0001-7091-3022

\section{Notes}

The authors declare no competing financial interest.

\section{ACKNOWLEDGMENTS}

The European Research Council and Ministry of Youth, Education and Sports of the Czech Republic are acknowledged for financial support of this work through projects 638857 and LM2015082, respectively. This work has been carried out thanks to the support of the A*MIDEX project (no. ANR-11IDEX-0001-02) funded by the "Investissements d'Avenir" French government program, managed by the French National Research Agency (ANR).

\section{REFERENCES}

(1) Ortiz, G. F.; Hanzu, I.; Djenizian, T.; Lavela, P.; Tirado, J. L.; Knauth, P. Alternative Li-Ion Battery Electrode Based on SelfOrganized Titania Nanotubes. Chem. Mater. 2009, 21, 63-67.

(2) Djenizian, T.; Hanzu, I.; Knauth, P. Nanostructured Negative Electrodes Based on Titania for Li-Ion Microbatteries. J. Mater. Chem. 2011, 21, 9925-9937.

(3) González, J. R.; Alcántara, R.; Nacimiento, F.; Ortiz, G. F.; Tirado, J. L.; Zhecheva, E.; Stoyanova, R. Long-Length Titania Nanotubes Obtained by High-Voltage Anodization and High-Intensity Ultrasonication for Superior Capacity Electrode. J. Phys. Chem. C 2012, 116, 20182-20190.

(4) Lee, K.; Mazare, A.; Schmuki, P. One-Dimensional Titanium Dioxide Nanomaterials: Nanotubes. Chem. Rev. 2014, 114, 93859454.

(5) Liu, H.; Bi, Z.; Sun, X.-G.; Unocic, R. R.; Paranthaman, M. P.; Dai, S.; Brown, G. M. Mesoporous $\mathrm{TiO}_{2}-\mathrm{B}$ Microspheres with Superior Rate Performance for Lithium Ion Batteries. Adv. Mater. 2011, 23, 3450-3454.

(6) Armstrong, A. R.; Armstrong, G.; Canales, J.; Bruce, P. G. TiO 2 -B Nanowires. Angew. Chem., Int. Ed. 2004, 43, 2286-2288.

(7) Armstrong, A. R.; Armstrong, G.; Canales, J.; García, R.; Bruce, P. G. Lithium-Ion Intercalation into $\mathrm{TiO}_{2}-\mathrm{B}$ Nanowires. Adv. Mater. 2005, 17, 862-865.

(8) Ren, Y.; Liu, Z.; Pourpoint, F.; Armstrong, A. R.; Grey, C. G.; Bruce, P. G. Nanoparticulate $\mathrm{TiO}_{2}(\mathrm{~B})$ : An Anode for Lithium-Ion Batteries. Angew. Chem., Int. Ed. 2012, 51, 2164-2167.

(9) Yang, M.-C.; Lee, Y. Y.; Xu, B.; Powers, K.; Meng, Y. S. TiO Flakes as Anode Materials for Li-Ion-Batteries. J. Power Sources 2012, 207, 166-172.

(10) Panda, S. K.; Lee, S.; Yoon, W.-S.; Shin, H. Reversible Phase Transformation of Titania (Anatase) Nanotubes upon Electrochemical Lithium-Intercalation Observed by Ex Situ Transmission Electron Microscopy. J. Power Sources 2014, 249, 59-65.

(11) Han, H.; Song, T.; Lee, E.-K.; Devadoss, A.; Jeon, Y.; Ha, J.; Chung, Y.-C.; Choi, Y.-M.; Jung, Y.-G.; Paik, U. Dominant Factors 
Governing the Rate Capability of a $\mathrm{TiO} 2$ Nanotube Anode for High Power Lithium Ion Batteries. ACS Nano 2012, 6, 8308-8315.

(12) Ellis, B. L.; Knauth, P.; Djenizian, T. Three-Dimensional SelfSupported Metal Oxides for Advanced Energy Storage. Adv. Mater. 2014, 26, 3368-3397.

(13) Salian, G. D.; Lebouin, C.; Demoulin, A.; Lepikhin, M. S.; Maria, S.; Galyyeva, A. K.; Kurbatov, A. P.; Djenizian, T. Electrodeposition of Polymer Electrolyte in Nanostructured Electrodes for Enhanced Electrochemical Performance of Thin-Film Li-Ion Microbatteries. J. Power Sources 2017, 340, 242-246.

(14) Plylahan, N.; Letiche, M.; Barr, M.; Ellis, B.; Maria, S.; Phan, T. N. T.; Bloch, E.; Knauth, P.; Djenizian, T. High Energy and Power Density $\mathrm{TiO}_{2}$ Nanotube Electrodes for Single and Complete LithiumIon Batteries. J. Power Sources 2015, 273, 1182-1188.

(15) Plylahan, N.; Letiche, M.; Barr, M.; Djenizian, T. All-Solid-State Li-Ion Batteries Based on Self-Supported Titania Nanotubes. Electrochem. Commun. 2014, 43, 121-124.

(16) Macak, J. M.; Tsuchiya, H.; Ghicov, A.; Yasuda, K.; Hahn, R.; Bauer, S.; Schmuki, P. $\mathrm{TiO}_{2}$ Nanotubes: Self-Organized Electrochemical Formation, Properties and Applications. Curr. Opin. Solid State Mater. Sci. 2007, 11, 3-18.

(17) Fang, D.; Huang, K.; Liu, S.; Li, Z. Electrochemical Properties of Ordered $\mathrm{TiO}_{2}$ Nanotube Loaded with Ag Nano-Particles for Lithium Anode Material. J. Alloys Compd. 2008, 464, L5-L9.

(18) Xue, L.; Wei, Z.; Li, R.; Liu, J.; Huang, T.; Yu, A. Design and Synthesis of $\mathrm{Cu}_{6} \mathrm{Sn}_{5}$-Coated $\mathrm{TiO}_{2}$ Nanotube Arrays as Anode Material for Lithium Ion Batteries. J. Mater. Chem. 2011, 21, 3216-3220.

(19) Ortiz, G. F.; Hanzu, I.; Lavela, P.; Tirado, J. L.; Knauth, P.; Djenizian, T. A Novel Architectured Negative Electrode Based on Titania Nanotube and Iron Oxide Nanowire Composites for Li-Ion Microbatteries. J. Mater. Chem. 2010, 20, 4041-4046.

(20) Ortiz, G. F.; Hanzu, I.; Lavela, P.; Knauth, P.; Tirado, J. L.; Djenizian, T. Nanoarchitectured $\mathrm{TiO}_{2} / \mathrm{SnO}$ : A Future Negative Electrode for High Power Density Li-Ion Microbatteries? Chem. Mater. 2010, 22, 1926-1932.

(21) Du, G.; Guo, Z.; Zhang, P.; Li, Y.; Chen, M.; Wexler, D.; Liu, H. $\mathrm{SnO}_{2}$ Nanocrystals on Self-Organized $\mathrm{TiO}_{2}$ Nanotube Array as ThreeDimensional Electrode for Lithium Ion Microbatteries. J. Mater. Chem. 2010, 20, 5689-5694.

(22) Wu, X.; Zhang, S.; Wang, L.; Du, Z.; Fang, H.; Ling, Y.; Huang, Z. Coaxial $\mathrm{SnO}_{2} @ \mathrm{TiO}_{2}$ Nanotube Hybrids: From Robust Assembly Strategies to Potential Application in $\mathrm{Li}^{+}$Storage. J. Mater. Chem. 2012, 22, 11151-11158.

(23) Li, R.; Xie, Z.; Lu, H.; Zhang, D. W.; Yu, A. Fabrication of $\mathrm{ZnO} @ \mathrm{TiO}_{2}$ Core-Shell Nanotube Arrays as Three-Dimensional Anode Material for Lithium Ion Batteries. Int. J. Electrochem. Sci. 2013, 8, 11118-11124.

(24) Tupala, J.; Kemell, M.; Härkönen, E.; Ritala, M.; Leskelä, M. Preparation of Regularly Structured Nanotubular $\mathrm{TiO}_{2}$ Thin Films on ITO and Their Modification with Thin ALD-Grown Layers. Nanotechnology 2012, 23, No. 125707.

(25) Macak, J. M.; Prikryl, J.; Sopha, H.; Strizik, L. Antireflection $\mathrm{In}_{2} \mathrm{O}_{3}$ Coatings of Self-Organized $\mathrm{TiO}_{2}$ Nanotube Layers Prepared by Atomic Layer Deposition. Phys. Status Solidi RRL 2015, 9, 516-520.

(26) Zazpe, R.; Knaut, M.; Sopha, H.; Hromadko, L.; Albert, M.; Prikryl, J.; Gärtnerová, V.; Bartha, J. W.; Macak, J. M. Atomic Layer Deposition for Coating of High Aspect Ratio $\mathrm{TiO}_{2}$ Nanotube Layers. Langmuir 2016, 32, 10551-10558.

(27) Cheah, S. K.; Perre, E.; Rooth, M.; Fondell, M.; Hårsta, A.; Nyholm, L.; Boman, M.; Gustafsson, T.; Lu, J.; Simon, P.; Edström, K. Self-Supported Three-Dimensional Nanoelectrodes for Microbattery Applications. Nano Lett. 2009, 9, 3230-3233.

(28) Scott, I. D.; Jung, Y. S.; Cavanagh, A. S.; Yan, Y.; Dillon, A. C.; George, S. M.; Lee, S.-H. Ultrathin Coatings on Nano- $\mathrm{LiCoO}_{2}$ for $\mathrm{Li}$ Ion Vehicular Applications. Nano Lett. 2011, 11, 414-418.

(29) Memarzadeh Lotfabad, E.; Kalisvaart, P.; Cui, K.; Kohandehghan, A.; Kupsta, M.; Olsen, B.; Mitlin, D. ALD $\mathrm{TiO}_{2}$ Coated Silicon Nanowires for Lithium Ion Battery Anodes With
Enhanced Cycling Stability and Coulombic Efficiency. Phys. Chem. Chem. Phys. 2013, 15, 13646-13657.

(30) Lotfabad, E. M.; Kalisvaart, P.; Kohandehghan, A.; Cui, K.; Kupsta, M.; Olsen, B.; Farbod, B.; Mitlin, D. Si Nanotubes ALD Coated With $\mathrm{TiO}_{2}$, TiN or $\mathrm{Al}_{2} \mathrm{O}_{3}$ As High Performance Lithium Ion Battery Anodes. J. Mater. Chem. A 2014, 2, 2504-2516.

(31) Zhang, H.; Ren, W.; Cheng, C. Three-Dimensional $\mathrm{SnO}_{2} @ \mathrm{TiO}_{2}$ Double-Shell Nanotubes on Carbon Cloth as a Flexible Anode for Lithium-Ion Batteries. Nanotechnology 2015, 26, No. 274002.

(32) Lv, X.; Deng, J.; Sun, X. Cumulative Effect of $\mathrm{Fe}_{2} \mathrm{O}_{3}$ on $\mathrm{TiO}_{2}$ Nanotubes via Atomic Layer Deposition with Enhanced Lithium Ion Storage Performance. Appl. Surf. Sci. 2016, 369, 314-319.

(33) Zhong, Y.; Ma, Y.; Guo, Q.; Liu, J.; Wang, Y.; Yang, M.; Xia, H. Controllable Synthesis of $\mathrm{TiO}_{2} @ \mathrm{Fe}_{2} \mathrm{O}_{3}$ Core-Shell Nanotube Arrays with Double-Wall Coating as Superb Lithium-Ion Battery Anodes. Sci. Rep. 2017, 7, No. 40927.

(34) Vetter, J.; Novak, P.; Wagner, M. R.; Veit, C.; Moller, K. C.; Besenhard, J. O.; Winter, M.; Wohlfahrt-Mehrens, M.; Vogler, C.; Hammouche, A. Ageing Mechanisms in Lithium-Ion Batteries. J. Power Sources 2005, 147, 269-281.

(35) Jung, Y. S.; Cavanagh, A. S.; Riley, L. A.; Kang, S.-H.; Dillon, A. C.; Groner, M. D.; George, S. M.; Lee, S.-H. Ultrathin Direct Atomic Layer Deposition on Composite Electrodes for Highly Durable and Safe Li-Ion Batteries. Adv. Mater. 2010, 22, 2172-2176.

(36) Liu, Y.; Hudak, N. S.; Huber, D. L.; Limmer, S. J.; Sullivan, J. P.; Huang, J. Y. In Situ Transmission Electron Microscopy Observation of Pulverization of Aluminum Nanowires and Evolution of the Thin Surface $\mathrm{Al}_{2} \mathrm{O}_{3}$ Layers during Lithiation-Delithiation Cycles. Nano Lett. 2011, 11, 4188-4194.

(37) Leung, K.; Qi, Y.; Zavadil, K. R.; Jung, Y. S.; Dillon, A. C.; Cavanagh, A. S.; Lee, S.-H.; George, S. M. Using Atomic Layer Deposition to Hinder Solvent Decomposition in Lithium Ion Batteries: First-Principles Modeling and Experimental Studies. J. Am. Chem. Soc. 2011, 133, 14741-14754.

(38) Lahiri, I.; Oh, S.-M.; Hwang, J. Y.; Chiwon Kang, C.; Choi, M.; Jeon, H.; Banerjee, R.; Sun, Y.-K.; Choi, W. Ultrathin Alumina-Coated Carbon Nanotubes as an Anode for High Capacity Li-Ion Batteries. J. Mater. Chem. 2011, 21, 13621-13626.

(39) Ahn, D.; Xiao, X. Extended Lithium Titanate Cycling Potential Window with Near Zero Capacity Loss. Electrochem. Commun. 2011, 13, 796-799.

(40) Nguyen, H. T.; Zamfir, M. R.; Duong, L. D.; Lee, Y. H.; Paolo Bondavallic, P.; Pribat, D. Alumina-Coated Silicon-Based Nanowire Arrays for High Quality Li-Ion Battery Anodes. J. Mater. Chem. 2012, 22, 24618-24626.

(41) Xiao, X.; Peng Lu, P.; Ahn, D. Ultrathin Multifunctional Oxide Coatings for Lithium Ion Batteries. Adv. Mater. 2011, 23, 3911-3915.

(42) He, Y.; Yu, X.; Wang, Y.; Li, H.; Huang, X. Alumina-Coated Patterned Amorphous Silicon as the Anode for a Lithium-Ion Battery with High Coulombic Efficiency. Adv. Mater. 2011, 23, 4938-4941.

(43) Lipson, A. L.; Puntambekar, K.; Comstock, D. J.; Meng, X.; Geier, M. L.; Elam, J. W.; Hersam, M. C. Nanoscale Investigation of Solid Electrolyte Interphase Inhibition on Li-Ion Battery $\mathrm{MnO}$ Electrodes via Atomic Layer Deposition of $\mathrm{Al}_{2} \mathrm{O}_{3}$. Chem. Mater. 2014, 26, 935-940.

(44) Das, S.; Sopha, H.; Krbal, M.; Zazpe, R.; Podzemna, V.; Prikryl, J.; Macak, J. M. Electrochemical Infilling of $\mathrm{CuInSe}_{2}$ within $\mathrm{TiO}_{2}$ Layers and Their Photoelectrochemical Studies. ChemElectroChem 2017, 4, 495-499.

(45) Albu, S. P.; Ghicov, A.; Aldabergenova, S.; Drechsel, P.; LeClere, D.; Thompson, G. E.; Macak, J. M.; Schmuki, P. Formation of DoubleWalled $\mathrm{TiO}_{2}$ Nanotubes and Robust Anatase Membranes. Adv. Mater. 2008, 20, 4135-4139.

(46) Zazpe, R.; Prikryl, J.; Gärtnerova, V.; Nechvilova, K.; Benes, L.; Strizik, L.; Jäger, A.; Bosund, M.; Sopha, H.; Macak, J. M. ALD $\mathrm{Al}_{2} \mathrm{O}_{3}$ Coatings Significantly Improve Thermal, Chemical and Mechanical Stability of Anodic $\mathrm{TiO}_{2}$ Nanotube Layers. Langmuir 2017, 33, 32083216. 
(47) Attia, A.; Zukalova, M.; Rathouský, J.; Zukal, A.; Kavan, L. Mesoporous electrode material from alumina-stabilized anatase $\mathrm{TiO}_{2}$ for lithium ion batteries. J. Solid State Electrochem. 2005, 9, 138-145.

(48) Deng, D.; Kim, M. G.; Lee, J. Y.; Cho, J. Green Energy Storage Materials: Nanostructured $\mathrm{TiO}_{2}$ and $\mathrm{Sn}$-Based Anodes for Lithium-Ion Batteries. Energy Environ. Sci. 2009, 2, 818-837.

(49) Jung, S. C.; Han, Y.-K. How Do Li Atoms Pass through the $\mathrm{Al}_{2} \mathrm{O}_{3}$ Coating Layer during Lithiation in Li-ion Batteries? J. Phys. Chem. Lett. 2013, 4, 2681-2685.

(50) Lindstrom, H.; Sodergren, S.; Solbrand, A.; Rensmo, H.; Hjelm, J.; Hagfeldt, A.; Lindquist, S. E. $\mathrm{Li}^{+}$Ion Insertion in $\mathrm{TiO}_{2}$ (Anatase). 1 . Chronoamperometry on CVD Films and Nanoporous Films. J. Phys. Chem. B 1997, 101, 7710-7716.

(51) Fang, D.; Li, L.; Xu, W.; Zheng, H.; Xu, J.; Jiang, M.; Liu, R.; Jiang, X.; Luo, Z.; Xiong, C.; Wang, Q. High Capacity Lithium Ion Battery Anodes Using Sn Nanowires Encapsulated $\mathrm{Al}_{2} \mathrm{O}_{3}$ Tubes in Carbon Matrix. Adv. Mater. Interfaces 2016, 3, No. 1500491. 